\title{
Immunomodulatory Effects of Tulathromycin in Rabbits
}

\author{
Sabry M. Abdel-Motal ${ }^{1}$, Gamal A. Shams ${ }^{1}$, Nagah E. Edress ${ }^{1}$, Abeer M. Anwer ${ }^{2}$ and Ghada A. \\ Mohamed $^{3 *}$ \\ ${ }^{1}$ Pharmacology Department, Faculty of Veterinary Medicine, Zagaig University, 44511, Egypt \\ ${ }^{2}$ Immunopharmacology Unit, Animal Reproduction Research Institute, Egypt \\ ${ }^{3}$ Directorate of Veterinary Medicine, Zagazig, Egypt
}

Article History: Received: 12/2/2015 Received in revised form: 23/8/2016 Accepted: 1/2/2017

\begin{abstract}
Tulathromycin is a new injectable macrolid antibiotic used for treating pulmonary disease. Therefore, the present work was aimed to study the effect of tulathromycin administration only or in a combination with vitamin $\mathrm{C}$ (immunomodatory agent) on immnomodulating, apoptotic effect and DNA of some immune cells. Moreover, to investigate its effect on serum antioxidant activity. Twenty-five apparently healthy rabbits were divided into 5 equal groups, the $1^{\text {st }}$ group was the control and the $2^{\text {nd }}$ was the vaccinated group with $1 \mathrm{~mL} /$ rabbit S.C "Pasteurella multocida vaccine". The $3^{\text {rd }}$ group injected with $17.5 \mathrm{mg} / \mathrm{rabbit}$ of vitamin $\mathrm{C}$ and $1 \mathrm{~mL} / \mathrm{rabbit}$ S.C "Pasteurella multocida vaccine" while, the $4^{\text {th }}$ group was given $1 \mathrm{~mL}$ S.C/rabbit Pasteurella multocida vaccine and $2.5 \mathrm{mg} / \mathrm{kg}$ BW tulathromycin. The $5^{\text {th }}$ group was treated S.C with 17.5 $\mathrm{mg} / \mathrm{rabbit}$ vitamin C, $1 \mathrm{~mL}$ Pasteurella multocida vaccine and $2.5 \mathrm{mg} / \mathrm{kg} \mathrm{BW}$ tulathromycin. The results showed a significant inhibition of lymphocyte transformation at $3^{\text {rd }}$ day, phagocytic activity and lysozyme activity at $1^{\text {st }}, 2^{\text {nd }}$ and $3^{\text {rd }}$ day of vaccination in the $4^{\text {th }}$ group. Moreover, its total globulin level was significantly depressed at the $7^{\text {th }}$ and $14^{\text {th }}$ day with a depression of antibody titre against pasteurella till the $3^{\text {rd }}$ week post vaccination. Comet results revealed a significant increase of DNA damage $\%$ on the $3^{\text {rd }}$ and $7^{\text {th }}$ days post vaccination. DNA fragmentation of neutrophil was transiently occurred in the $3^{\text {rd }}$ and $7^{\text {th }}$ days post treatment. It was concluded that, Tulathromycin has a transient immunosuppressive and genotoxic effect, therefore it should be administered in a combination with Vit $C$ to overcome its side effects.
\end{abstract}

Keywords: Tulathromycin, Vitamin C, Immunity, Genotoxicity, Rabbits

\section{Introduction}

Macrolides are a group of antibiotics that have an anti-inflammatory activity, which used in treatment of diffuse pan-bronchiolitis and cystic fibrosis [1]. They have variety of physiological functions, such as anti-viral effects, reduction of sputum production, inhibition of biofilm formation and bacterial virulence factor production [2]. Macrolides have immunosuppressive properties for both cellular and humoral immune responses [3].

Tulathromycin is a semi-synthetic macrolide antimicrobial agent, the chemical formula of the drug is $\mathrm{C}_{41} \mathrm{H}_{79} \mathrm{~N}_{3} \mathrm{O}_{12}$. It is a potent injectable solution and the recommended therapeutic dose is a single dose of $2.5 \mathrm{mg} / \mathrm{kg} \mathrm{BW} \mathrm{S.C} \mathrm{[4].} \mathrm{It's} \mathrm{administered} \mathrm{at}$ a single dose in cattle for controlling and treating bovine respiratory disease caused by Pasteurella multocida, Haemophilus somnus, Actinobacillus pleuropneumonia and recently
Moraxella bovoculi [5]. The present work aimed to study the effect of tulathromycin administration only or in a combination with vitamin $\mathrm{C}$ (immunomodatory agent) on immnomodulating, apoptotic effect and DNA of some immune cells. Moreover, to investigate its effect on serum antioxidant activity using rabbit as a model.

\section{Material and Methods}

\section{Experimental animals}

The present study was conducted on twenty-five apparently healthy rabbits (3 month old) weighing $2 \pm 0.25 \mathrm{~kg} / \mathrm{rabbit}$, obtained from Laboratory Animal House, Faculty of Veterinary Medicine, Zagazig University. They were divided into 5 equal groups. All groups were vaccinated with $P$. multocida vaccine $(1 \mathrm{~mL} / \mathrm{rabbit}, \mathrm{S} . \mathrm{C}$; oil adjuvant polyvalent rabbit $P$. multocida vaccine $\left(4 \times 10^{9} / \mathrm{mL}\right.$ CFU of $P$. multocida,

*Corresponding author email: (ghada_sharkawy97@yahoo.com), Directorate of Veterinary Medicine,

Zagazig, 44511, Egypt. 
Vaccine and Sera Institute in Abbasia, Cairo, Egypt) except the first group that was left as a control group (non-vaccinated). The $3^{\text {rd }}$ and $5^{\text {th }}$ groups were administered $17.5 \mathrm{mg}$ Vit. C/rabbit S.C (Cevarol ${ }^{\circledR}$, ampules of $5 \mathrm{ml}$, each contain $1000 \mathrm{mg}$ vitamin C; Memphis Pharmaceutical and Chemical Industries (MPCI), Egypt) for 10 successive days. The therapeutic dose of vitamin $\mathrm{C}$ in humans was $250 \mathrm{mg} / \mathrm{kg}$ BW/once daily [6] which was converted to the rabbit dose $17.5 \mathrm{mg} / \mathrm{kg} \mathrm{BW}$ [7]. The $4^{\text {th }}$ and $5^{\text {th }}$ group received a single dose of tulathromycin (Draxxin ${ }^{\circledR}$, Pfizer Co., Egypt, $2.5 \mathrm{mg} / \mathrm{kg}$ BW S.C). Two Blood samples were collected from each rabbit; the first samples were collected on heparinized tube at the $1^{\text {st }}, 3^{\text {rd }}, 7^{\text {th }}, 14^{\text {th }}$ and $21^{\text {st }}$ days post vaccination, while the second samples were collected without anticoagulant at the $7^{\text {th }}, 14^{\text {th }}$, $21^{\text {th }}$ and $28^{\text {th }}$ days post vaccination.

\section{Measurement of Lysozyme activity, lymphocyte proliferation and phagocytic activity of macrophage}

Lysozyme activity was estimated by the diameter of the clear zone ring of lysis that developed in the translucent agarose gel after diffusion of lysozymes through the agarose gel containing a suspension of Micrococcus lysodeikticus [8]. The lymphocyte proliferative response was evaluated via lymphocyte separation by centrifugation through a ficollhypaque at $400 \mathrm{xg}$. The number of lymphocyte was concentrated as $1 \times 10^{6}$ cells $/ \mathrm{mL}$ and cultured in 96 well tissue culture plate with $10 \%$ fetal calf serum at $37^{\circ} \mathrm{C}$ and $5 \% \mathrm{CO}_{2}$ for $72 \mathrm{~h}$. Proliferation of lymphocytes in response to phytohemagglutinin mitogen was estimated using MTT reduction assay [9]. Phagocytic activity of macrophage was determined by incubating a mixture of Candida and macrophage at $37^{\circ} \mathrm{C}$ for $2 \mathrm{~h}$ with regular stirring and then centrifugated at $2000 \mathrm{rpm}$. for $5 \mathrm{~m}$ at $4^{\circ} \mathrm{C}$. The sediment was smeared on glass slide and stained with Leishman stain to examine 100 cells. Consequently, the total number of phagocytic cells, number of phagocyte with ingested Candida cells and number of ingested Candida cells in each phagocyte were determined [10].

\section{Comet assay}

The genotoxic effect of Tulathromycin on neutrophil was estimated using comet assay.
And DNA damage was determined according to Singh et al. [11]. A volume of $10 \mu \mathrm{L}$ of cell sediment was mixed with $90 \mu \mathrm{L}$ of low melting point agarose $(0.7 \%$ in $\mathrm{PBS})$ at $37^{\circ} \mathrm{C}$ and added to a fully frosted microscope slide coated with normal melting point agarose, the slides were placed in lysis buffer $(2.5 \mathrm{~mol} / \mathrm{L}$ $\mathrm{NaCl}, 100 \mathrm{mmol} / \mathrm{L}$ Na2EDTA, $10 \mathrm{mmol} / \mathrm{L}$ Tris, ( $\mathrm{pH} 10)$ ) with freshly added $1 \%$ Triton $\mathrm{X}-100$ and $10 \%$ DMSO for $2 \mathrm{~h}$ at $4^{\circ} \mathrm{C}$. Subsequently, unwinding in alkaline buffer (300 mmol/L NaOH, $1 \mathrm{mmol} / \mathrm{L}$ Na2EDTA $(\mathrm{pH}>13))$ for $15 \mathrm{~min}$ at $4^{\circ} \mathrm{C}$ and electrophoresis for $30 \mathrm{~min}$ at $25 \mathrm{~V}$ and 300 $\mathrm{mA}$. The slides were neutralized $(0.4 \mathrm{~mol} / \mathrm{L}$ Tris $(\mathrm{pH} 7.5))$ and stained $(50 \mu \mathrm{L}$ of ethidium bromide $(2 \mathrm{mg} / \mathrm{mL})$ ) then observed using Optika Axioscope fluorescence microscope at 400 magnifications. For each sample 100 cells were photographed and scanned. For each cell, the length of DNA migration (tail length), the percentage of DNA in the tail and the tail moment was estimated.

\section{Fragmentation of DNA (apoptotic effects)}

The extraction buffer $(500 \mu \mathrm{L})$ was mixed with $200 \mu \mathrm{L}$ of cell suspension in $1.5 \mathrm{~mL}$ microfuge tube and then $50 \mu \mathrm{L}$ of Proteinase$\mathrm{K}$ solution $(10 \mathrm{mg} / \mathrm{mL})$ was added and incubated at $37^{\circ} \mathrm{C}$ overnight. Subsequently, 0.7-0.8 mL phenol: chloroform: isoamylalcohol, in 25:24:1 was added and vortexed for 2-5 sec, followed by centrifugation at $12.000 \mathrm{rpm}$ for 3-5 min. The aqueous layer (400-500 $\mu \mathrm{L})$ of each sample was removed to a new tube and $40-50 \mu \mathrm{L} 3 \mathrm{M}$ sodium acetate $\mathrm{pH} 5.3$ was added to each tube, ethanol $100 \%$ was added till mark $1.5 \mathrm{~mL}$ and inverted to mix and DNA was let to set at $20^{\circ} \mathrm{C}$ overnight, then centrifuged at 12.000 rpm for 20min. The supernatant was then removed and the pellet was dissolved with $50 \mu \mathrm{L}$ of tris EDTA buffer overnight till complete dissolving. Finally, the samples were run on electrophoresis (1.2\% agarose and 50 volt) and the gel was stained using ethidium bromide. Samples were analyzed using image analyses software [12].

\section{Serum total proteins, albumin and globulin level}

The total proteins and albumin levels were estimated $[13,14]$. The serum globulin level 
was obtained by subtraction of the total proteins and albumin.

\section{Determination of antibody titer using ELISA}

It was applied to determine the effect of the tested drug on the titer of antibody against $P$. multocida after vaccination [15].

\section{Statistical analysis}

Statistical analysis of the results was carried out using student's T-test [16]. All the experimental groups were compared.

\section{Results}

\section{Estimation of cellular immune responses}

The effect of S.C administration of Tulathromycin $2.5 \mathrm{mg} / \mathrm{kg} \mathrm{BW}$ given once, vitamin C $17.5 \mathrm{mg} / \mathrm{rabbit}$ administered for 10 successive days and their combination on serum lysozyme levels, lymphocyte transformation index and phagocytic percentage in rabbits vaccinated against $P$. multocida vaccine was depicted in Table (1).

\section{Serum lysozyme level}

Tulathromycin induced a significant decrease in lysozyme levels $11.47 \pm 0.45 \mu \mathrm{g} / \mathrm{mL}$ $(9.91 \%)$ on the $1^{\text {st }}$ day, $11.47 \pm 1.77(9.05 \%)$ the $2^{\text {nd }}$ day and $13.38 \pm 1.69(9.52 \%)$ the $3^{\text {rd }}$ day post vaccination when compared with vaccinated group. Co-administration of vitamin $\mathrm{C}$ with Tulathromycin elicited a significant increase in lysozyme levels $16.50 \pm 1.03 \mu \mathrm{g} / \mathrm{mL}(15.82 \%)$ on the $1^{\text {st }}$ day, $16.10 \pm 2.04(13.97 \%)$ the $2^{\text {nd }}$ day and $13.18 .25 \pm 1.85(14.53 \%)$ the $3^{\text {rd }}$ day post vaccination when compared with Tulathromycin group.

\section{Lymphocyte transformation assay}

Tulathromycin induced a significant decrease of lymphocyte transformation $0.811 \pm 0.003(49.15 \%)$ on the $3^{\text {rd }}$ day post vaccination when compared with the vaccinated group. Concurrent administration of vitamin $\mathrm{C}$ and Tulathromycin evoked a significant increase in lymphocyte transformation $1.33 \pm 0.004(158.64 \%)$ on the $3^{\text {rd }}$ day post vaccination when compared with tulathromycin group.

\section{Phagocytic activity of macrophage}

Tulathromycin induced a significant decrease in phagocytic $\% 5.20 \pm 0.12 \%(7.72 \%)$ on the $1^{\text {st }}$ day, $4.60 \pm 0.42(6.75 \%)$ the $2^{\text {nd }}$ day and $4.00 \pm 0.31(5.78 \%)$ the $3^{\text {rd }}$ day post vaccination when compared with the vaccinated group, while co-administration of vitamin $\mathrm{C}$ with Tulathromycin evoked a significant increase in phagocytic \% $6.00 \pm 0.41 \%(9.65 \%)$ on the $1^{\text {st }}$ day, $6.30 \pm 0.23$ $(9.75 \%)$ the $2^{\text {nd }}$ day and $\left.6.00 \pm 0.459 .20 \%\right)$ the $3^{\text {rd }}$ day post vaccination when compared with Tulathromycin group.

\section{Estimation of humoral immune responses}

The antibody titer against $P$. multocida using ELISA in rabbits as illustrated in Table (2). Tulathromycin induced a non-significant decrease in total globulins levels when compared with vaccinated group, while concurrent administration of vitamin $\mathrm{C}$ with Tulathromycin evoked a non-significant increase in total globulins levels when compared with Tulathromycin group. Tulathromycin induced a significant decrease in antibody titer $0.006 \pm 0.001(5.45 \%)$ on the $7^{\text {th }}$ day, $0.008 \pm 0.001(7.08 \%)$ on the $14^{\text {th }}$ day and $0.008 \pm 0.003(7.02 \%)$ on the $21^{\text {th }}$ day post vaccination when compared with vaccinated group, while concurrent administration of vitamin $\mathrm{C}$ with Tulathromycin evoked a significant increase in antibody titre $0.006 \pm 0.005(5.77 \%)$ on the $7^{\text {th }}$ day, $0.007 \pm 0.003(6.67 \%)$ on the $14^{\text {th }}$ day and $0.10 \pm 0.006(9.43 \%)$ on the $21^{\text {th }}$ day post vaccination when compared with Tulathromycin group. 


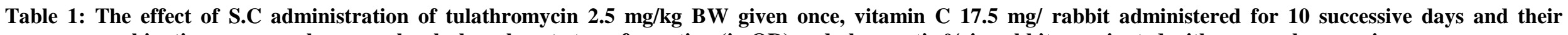
combination on serum lysozyme levels, lymphocyte transformation (in OD) and phagocytic \% in rabbits vaccinated with pneumobac vaccine

\begin{tabular}{|c|c|c|c|c|c|c|c|c|}
\hline \multirow{3}{*}{ Group } & \multicolumn{3}{|c|}{$\begin{array}{c}\text { Serum lysozyme levels } \\
(\mu \mathrm{g} / \mathrm{ml})\end{array}$} & \multicolumn{2}{|c|}{$\begin{array}{c}\text { Lymphocyte transformation } \\
\text { index }\end{array}$} & \multicolumn{3}{|c|}{$\begin{array}{c}\text { Phagocytic } \\
\% \\
\end{array}$} \\
\hline & \multicolumn{8}{|c|}{ Time post vaccination (day) } \\
\hline & $\mathbf{1}^{\text {st }}$ & $2^{\text {nd }}$ & $3^{\text {rd }}$ & $3^{\text {rd }}$ & $7^{\text {th }}$ & $1^{\text {st }}$ & $2^{\text {nd }}$ & $3^{\text {rd }}$ \\
\hline 1) Control & $89.67 \pm 4.73$ & $87.30 \pm 6.70$ & $89.67 \pm 4.33$ & $1.23 \pm 0.004$ & $1.35 \pm 0.006$ & $61.40 \pm 0.24$ & $61.20 \pm 0.37$ & $61.20 \pm 0.37$ \\
\hline 2) Vaccinated & $115.78^{* *} \pm 6.7$ & $126.4^{* * * *} \pm 5$ & $140.5^{* * * *} \pm 4.43$ & $1.65^{*} \pm 0.006$ & $1.56 \pm 0.005$ & $67.4^{++} \pm 0.51$ & $68.2^{* * * *} \pm 0.55$ & $69.2^{* * * *} \pm 0.37$ \\
\hline 3) Vaccinated + vit. C & $123.77^{+} \pm 7$ & $135.2^{+} \pm 6.7$ & $150.73^{+} \pm 5.07$ & $2.38^{+++} \pm 0.005$ & $1.65 \pm 0.007$ & $73^{++} \pm 0.31$ & $74^{++} \pm 0.44$ & $75.80^{++} \pm 0.37$ \\
\hline 4) Vaccinated + tulathromycin & $104.31^{+} \pm 7$ & $115.3^{+} \pm 5.7$ & $127.15^{++} \pm 6$ & $0.839^{+++} \pm 0.003$ & $1.42 \pm 0.006$ & $62.2^{++} \pm 0.37$ & $63.6^{++} \pm 0.51$ & $65.2^{+} \pm 0.37$ \\
\hline 5) Vaccinated+vit.C+tulathromycin & $120.8^{\theta \theta} \pm 6$ & $131.4^{\theta \theta} \pm 7.7$ & $145.4^{\theta \theta} \pm 4.33$ & $2.17^{\theta \theta \theta} \pm 0.007$ & $1.52 \pm 0.005$ & $68.2^{\theta \theta} \pm 0.37$ & $69.8^{\theta \theta} \pm 0.37$ & $71.2^{\theta \theta} \pm 0.37$ \\
\hline
\end{tabular}

$* \mathrm{P}<0.05 \quad * * \mathrm{P}<0.01$

$+++\mathrm{P}<0.001$

$\theta \mathrm{P}<0.05$

* Compared with control group

$* * * \mathrm{P}<0.001$

$+\mathrm{P}<0.05$

$++\mathrm{P}<0.01$

+ Compare

$\theta$ Compared with vaccinated + tulathromycin

Table 2: The effect of S.C administration of tulathromycin $2.5 \mathrm{mg} / \mathrm{kg}$ BW given once, vitamin $\mathrm{C} 17.5 \mathrm{mg} / \mathrm{rabbit}$ administered for 10 successive days and their combination on serum total globulins levels and antibody titer levels using ELISA test in rabbits vaccinated with pneumobac vaccine

\begin{tabular}{|c|c|c|c|c|c|c|c|c|}
\hline \multirow[t]{2}{*}{ Group } & \multicolumn{4}{|c|}{$\begin{array}{c}\text { Serum total globulins levels } \\
\text { (g/dl) } \\
\text { Time (post vaccination) } \\
\text { Day } \\
\end{array}$} & \multicolumn{4}{|c|}{$\begin{array}{c}\text { Antibody titer } \\
\text { Time (post vaccination) } \\
\text { Day }\end{array}$} \\
\hline & $7^{\text {th }}$ & $14^{\text {th }}$ & $21^{\text {th }}$ & $28^{\text {th }}$ & $7^{\text {th }}$ & $14^{\text {th }}$ & $21^{\text {th }}$ & $28^{\text {th }}$ \\
\hline 1) Control & $2.68 \pm 0.16$ & $3.02 \pm 0.15$ & $2.79 \pm 0.14$ & $2.97 \pm 0.15$ & $0.092 \pm 0.002$ & $0.089 \pm 0.003$ & $0.095 \pm 0.003$ & $0.091 \pm 0.006$ \\
\hline 2) Vaccinated & $3.74^{* \prime *} \pm 0.13$ & $3.78^{*} \pm 0.11$ & $3.49 \pm 0.12$ & $2.81 \pm 0.14$ & $0.110^{* * * *} \pm 0.001$ & $0.113^{* *} \pm 0.001$ & $0.114^{* * * *} \pm 0.005$ & $0.114 \pm 0.009$ \\
\hline 3) Vaccinated + vit. C & $4.04 \pm 0.12$ & $4.05 \pm 0.15$ & $3.72 \pm 0.13$ & $2.86 \pm 0.14$ & $0.112 \pm 0.002$ & $0.115 \pm 0.002$ & $0.118 \pm 0.001$ & $0.116 \pm 0.008$ \\
\hline 4) Vaccinated + tulathromycin & $3.32 \pm 0.15$ & $3.59 \pm 0.13$ & $3.41 \pm 0.14$ & $2.73 \pm 0.05$ & $0.104^{+} \pm 0.002$ & $0.105^{+} \pm 0.001$ & $0.106^{+} \pm 0.002$ & $0.113 \pm 0.012$ \\
\hline 5) Vaccinated+vit.C+tulathromycin & $3.82 \pm 0.15$ & $3.91 \pm 0.12$ & $3.74 \pm 0.14$ & $2.86 \pm 0.11$ & $0.110^{\theta} \pm 0.008$ & $0.112^{\theta} \pm 0.002$ & $0.116^{\theta} \pm 0.005$ & $0.112 \pm 0.003$ \\
\hline
\end{tabular}

5) Vaccinated+vit.C+tulathromycin

\section{$* * * \mathrm{P}<0.001$}

$+++\mathrm{P}<0.001 \quad \theta \mathrm{P}<0.05$

$*$ Compared with control group $\theta \theta \mathrm{P}<0.01$

$* * \mathrm{P}<0.01$

+ Compared with vaccinated.

$$
+\mathrm{P}<0.05 \quad++\mathrm{P}<0.01
$$

$\theta \theta \theta \mathrm{P}<0.001$

$\theta$ Compared with vaccinated + tulathromycin 


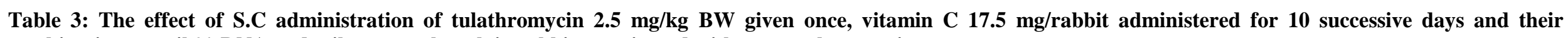
combination on tail \% DNA and tail moment length in rabbits vaccinated with pneumobac vaccine

\begin{tabular}{|c|c|c|c|c|c|c|c|c|}
\hline \multirow{2}{*}{ Group } & \multicolumn{8}{|c|}{$\begin{array}{c}\text { Comet assay } \\
\text { Time (post vaccination) } \\
\text { Day }\end{array}$} \\
\hline & Tail \% DNA & Tail moment & Tail \% DNA & Tail moment & Tail \% DNA & Tail moment & Tail \% DNA & Tail moment \\
\hline 1) Control & $12.43 \pm 0.23$ & $1.27 \pm 0.005$ & $12.3 \pm 0.17$ & $1.18 \pm 0.008$ & $13.7 \pm 0.14$ & $1.06 \pm 0.008$ & $12.3 \pm 0.17$ & $0.964 \pm 0.001$ \\
\hline 2) Vaccinated & $11.5 \pm 0.15$ & $1.38 \pm 0.005$ & $13.21 \pm 0.14$ & $1.25 \pm 0.004$ & $13.5 \pm 0.29$ & $1.09 \pm 0.007$ & $3.2 \pm 0.11$ & $0.984 \pm 0.006$ \\
\hline 3) Vaccinated + vit. C & $9.8 \pm 0.17$ & $1.02 \pm 0.008$ & $11.2 \pm 0.15$ & $1.03 \pm 0.001$ & $12.1 \pm 0.18$ & $0.981 \pm 0.001$ & $12.2 \pm 0.15$ & $0.967 \pm 0.001$ \\
\hline 4)Vaccinated+ tulathromycin & $20.6^{++} \pm 0.16$ & $3.54^{++} \pm 0.015$ & $21.40^{++} \pm 0.23$ & $3.15 \pm 0.013$ & $14.8 \pm 0.15$ & $1.26 \pm 0.004$ & $14.5 \pm 0.26$ & $1.22 \pm 0.006$ \\
\hline 5) Vaccinated + vitC + tulathromycin & $21.5 \pm 0.18$ & $3.22 \pm 0.018$ & $19.80 \pm 0.26$ & $3.28 \pm 0.011$ & $14.4 \pm 0.22$ & $1.12 \pm 0.002$ & $13.9 \pm 0.44$ & $0.996 \pm 0.006$ \\
\hline $\begin{array}{l}* \mathrm{P}<0.05 \\
+++\mathrm{P}<0.001\end{array}$ & & $\theta \theta \mathrm{P}<0.0$ & $P<0.001$ & $\begin{array}{l}+\mathrm{P}<0.0 \\
\theta \theta \theta \mathrm{P}<0\end{array}$ & & $++\mathrm{P}<$ & & \\
\hline
\end{tabular}




\section{Genotoxicity and Comet assay for neutrophil}

The genotoxic effect expressed by "DNA fragmentation assay" and comet assay in Table (3) and Figures (1 and 2). Tulathromycin induced a significant increase in DNA\% in tail $9.10 \pm 0.14 \%(79.13 \%)$ on the $3^{\text {rd }}$ day, $8.19 \pm 0.13(61.98 \%)$ on the $7^{\text {th }}$ day and nonsignificant changes on the $14^{\text {th }}$ and $21^{\text {th }}$ day post vaccination when compared with the vaccinated group. Tulathromycin induced a significant increase in tail moment length
$2.16 \pm 0.004(156.52 \%)$ on the $3^{\text {rd }}$ day, $1.90 \pm 0.002(152.00 \%)$ on the $7^{\text {th }}$ day and nonsignificant differences on the $14^{\text {th }}$ and $21^{\text {th }}$ days post vaccination when compared with the vaccinated group.

\section{Estimation of DNA fragmentation in neutrophil}

Rabbits given Tulathromycin showed double fragmentation in DNA of neutrophil on the $3^{\text {rd }}$ and $7^{\text {th }}$ day post vaccination when compared with vaccinated group.

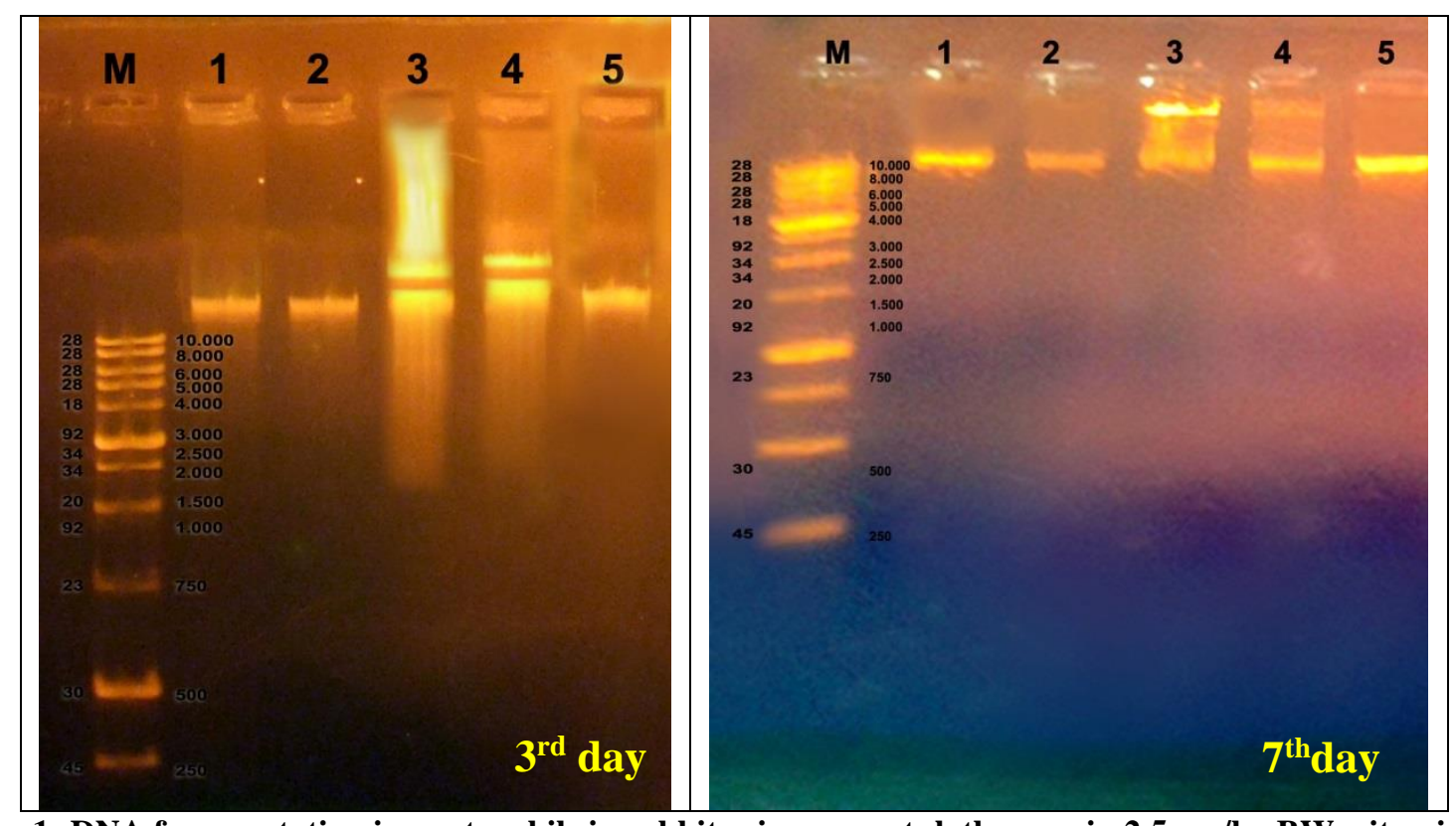

Figure 1: DNA fragmentation in neutrophils in rabbits given once tulathromycin $2.5 \mathrm{mg} / \mathrm{kg} \mathrm{BW}$, vitamin C 10 $\mathrm{mg} / \mathrm{kg} \mathrm{BW}$ for 10 successive days and their combination. DNA revealed double fragmentation and tail on the $3^{\text {rd }}$ day and $7^{\text {th }}$ post vaccination. M: Genomic DNA Marker, Lane 1: control group, Lane 2: vaccinated group, Lane 3: vaccinated + tulathromycin group, Lane 4: vaccinated + tulathromycin + vitamin C group and Lane 5: vaccinated + vitamin $\mathrm{C}$ group.

\section{Discussion}

In the current study, the serum lysozyme levels, lymphocyte transformation assay and phagocytic percent was significantly decreased in Tulathromycin treated rabbits that vaccinated with $P$. multocida vaccine. Likewise, Kohyama et al. [17] observed that treatment with 14-member of macrolides inhibit IL- 8 release by eosinophils and may prevent the autocrine cycle necessary for the recruitment of these cells into the airways. Macrolides inhibit the production of many proinflammatory cytokines such as interleukin IL1, IL-6, IL-8 and TNF- $\alpha$, possibly by suppressing the transcription factor nuclear ${ }_{\mathrm{k}} \mathrm{B}$ or activator protein-1 [18]. Macrolides suppress neutrophil migration through interfering with (i) Production of IL-8 and TNF- $\alpha$ by macrophages and structural cells, (ii) Decreased expression of adhesion molecules on vascular endothelium and neutrophils and (iii) Decrease production and release enzymes by neutrophils [19].

In a similar view, [20] reported that macrolides could potentially reduce the number of lymphocytes in the lungs of patients with chronic lower respiratory tract disease. Macroloides decline the proliferation of $\mathrm{T}$ lymphocytes by interfering with (i) expression of nuclear factor Kappa-light-chain-enhancer of activated $\mathrm{B}$ cells $\left(\mathrm{NF}_{\mathrm{k}} \mathrm{B}\right)$, (ii) cellular (JNK) 
c-Jun N-terminal kinases and (ERK) extracellular-signal-regulated kinases, and (iii) IFN- $\gamma$ levels [21]. These findings were in agreement with Kikuchi et al. [22] who found that macrolides suppress macrophages by suppression of cytokine production (IL-1B, IL6 , IL-8, TNF- $\alpha$ ), interfering with intracellular signaling mechanisms and transcription factor activation, resulting in suppression of gene expression and other mechanism through decreasing $\mathrm{NO}$ production by decreased the expression of gene encoding iNOS. Shortening of neutrophil survival was mediated indirectly through inhibition of GM-CSF (granulocyte monocyte-colony stimulating factor) released from epithelial cells or IL-8 production in activated neutrophils [23].
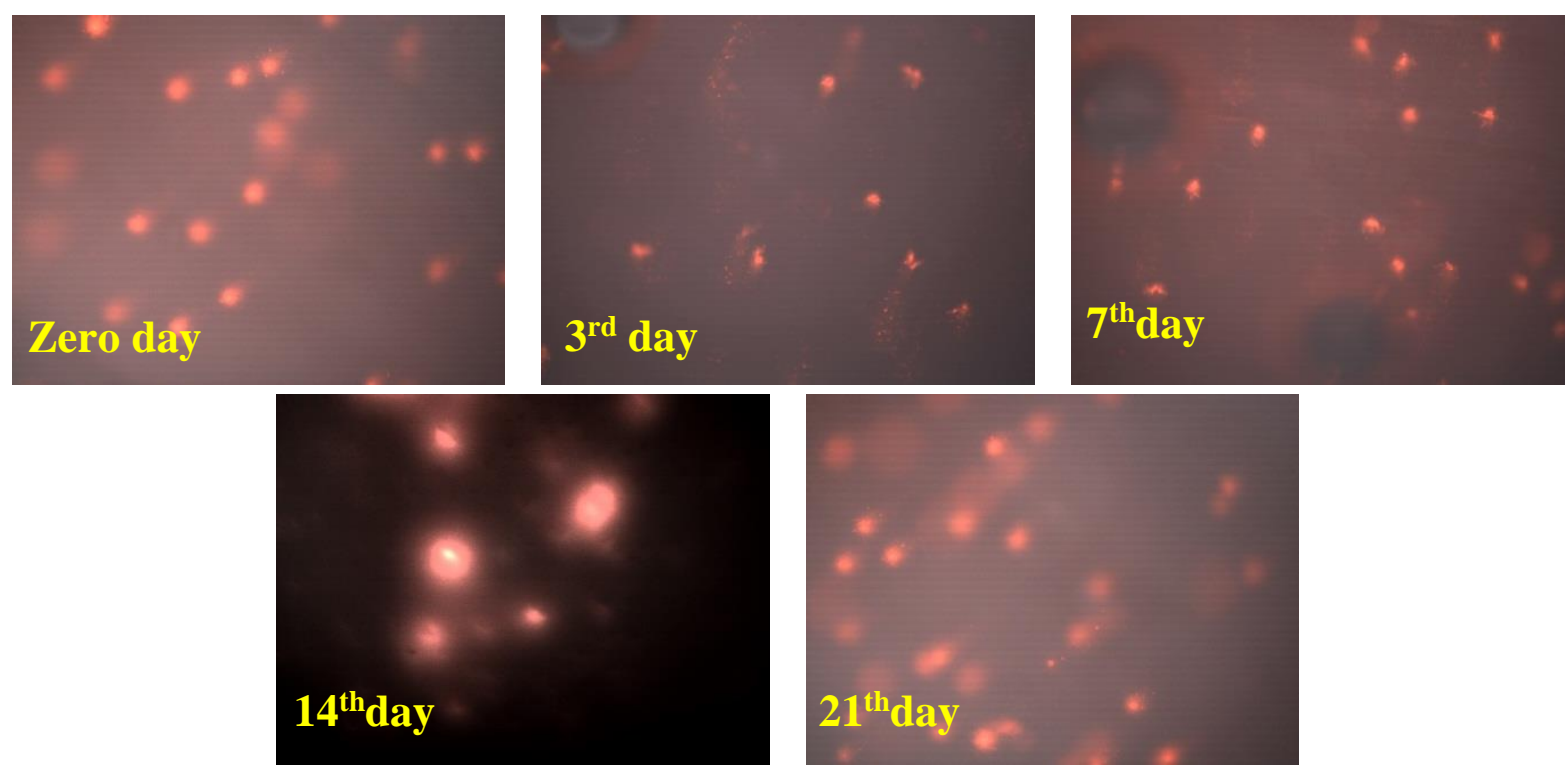

Figure 2: DNA of lymphocytes, macrophages and neutrophils in rabbits administered Tulathromycin depicting nuclei from damaged leukocytes consisted of a head with DNA migrating into tail region as a result of strand breakage on the $3^{\text {rd }}$ and $7^{\text {th }}$ day post vaccination.

In the current study, it was evinced that subcutaneously administration of Tulathromycin provoked a significant decrease in serum total proteins levels and antibody titer compared with pneumobac vaccine. In accordance, Luo et al. [24] found that in vitro Rapamycin had direct suppressive effect on B cells, so that Rapamycin suppressed $\mathrm{IgG}$ production by pure $\mathrm{B}$ cells stimulated with IL2, while measuring IgG production and cell proliferation revealed that Rapamycin acted at the activation stage of $\mathrm{T}$ and $\mathrm{B}$ cells. Therefore, Rapamycin had a strong suppressive effect on antibody titer. In the current study, we found that Tulathromycin evoked apoptosis in neutrophils. Likewise, Jun et al. [25] demonstrated that macrolides shorten neutrophil survival by accelerating neutrophil apoptosis. Moreover, Luo et al. [24] reported that Roxithormycin induced apoptosis by enhancing $\mathrm{FaS}-\mathrm{FaS}$ ligand and caspase-3 but not caspase-8. Tulathromycin with superior clinical efficacy promotes neutrophil apoptosis, which in turn leads to inhibition of the $\mathrm{NF}_{\mathrm{k}} \mathrm{B}$ pathway and downstream production of pro-inflammatory mediators. Caspases cleavage $\left(\mathrm{NF}_{-\mathrm{k}} \mathrm{B}\right.$ nuclear factor kappa B cells) proteins during apoptosis prevented the transcription of many proinflammatory and prosurvival genes [26].

In the current work, The Tulathromycin treated group displayed genotoxicity (DNA fragmentation) through a significant increase in DNA percent in the comet tail and tail moment in groups challenged with pneumobac vaccine. These findings coincide with Maletic et al. [27] who noted that Tulathromycin induces genotoxic effects. Neutrophils lose some of their secretory properties and undergo distinct of chromatin, and DNA fragmentation [28]. An early biochemical change during apoptosis is the loss of membrane 
phospholipid asymmetry, as phosphatidyl serine translocates to the outer leaflet of the plasma membrane [29].

\section{Conclusion}

It was concluded that, Tulathromycin has transient immunosuppressive and genotoxic side effects which can be avoided using immunostimulant and antioxidant such as Vit $\mathrm{C}$ to overcome these side effects.

\section{Conflict of interest}

None of the authors have any conflict of interest

\section{Acknowledgement}

We acknowledge Dr. Sahar Samir, Senior Researcher, Animal Health Research Institute, Zagazig Branch for her help.

\section{References}

[1] da Silva, L.V.R.F.; Pinto L.A. and Stein, R.T. (2015): Use of macrolides in lung diseases: recent literature controversies. J Pediatr, 91(6):S52-S60.

[2] Cameron, E.J.; McSharry, C.; Chaudhuri, R.; Farrow, S. and Thomson, N.C. (2012): Long term macrolide treatment of chronic inflammatory airway diseases: risks, benefits and future developments. Clin Exp Allergy, 42 (9): 1302-1312.

[3] Plessers, E.; Wyns, H.; Watteyn, A.; Pardon, B.; De Baere, S.; Sys, S.U.; De Backer, P. and Croubels, S. (2016): Immunomodulatory properties of gamithromycin and ketoprofen in lipopolysaccharide-challenged calves with emphasis on the acute-phase response. Vet Immunol Immunopathol, 171:28-37.

[4] Villarino, N.; Brown, S.A. and MartínJiménez, T. (2013): The role of the macrolide tulathromycin in veterinary medicine. Vet J, 198 (2): 352-357.

[5] Angelos, J.A.; Ball, L.M. and Byrne, B.A. (2011): Minimum inhibitory concentrations of selected antimicrobial agents for Moraxella bovoculi associated with infectious bovine keratoconjunctivitis. J Vet Diagn Invest, 23 (3): 552-555.

[6] Robert, F. and Cathcart, M.D. (1984): Vitamin $\mathrm{C}$ in the treatment of acquired immune deficiency syndrome. Med Hypotheses, 14(4): 423-433.

[7] Paget, G. and Barnes, J. (1964): Toxicity Tests. In: Evaluation of Drug Activities: Pharmacometrics. Laurance, D.R. and Bacharach, A.L. (eds.), Academic Press, London and New York, pp 135-166.

[8] Schltz, L.A. (1987): Methods in clinical chemistry. The CV Mosby Co. St Louis, USA, pp: 742-746.

[9] Rai-el-balhaa, G.; Pellerian, J.L.; Bodin, G.; Abdullah, H.A. and Hiron, H. (1985): Lymphocyte transformation assay of sheep peripheral blood lymphocytes. A new rapid and easy to read technique. Comp Immunol Microbial Inf Dis, 8(3): 311-318.

[10] Lucy, F.L. and Larry, D.B. (1982): Ontogeny and line differences as in mitogenic responses of chicken lymphocytes. Poult Sci, 62: 579-594.

[11] Singh, N.P.; McCoy, M.T.; Tice, R.R. and Schneider, E.L. (1988): Asimple technique for quantitation of low levels of DNA damage in individual cells. Exp Cell Res, 175(1): 184-191.

[12] Ribble, D.; Goldstein, N.; Norris, D.A. and Shellman, G.S. (2005): A simple technique for quantifying apoptosis in 96 well plates. BMC Biotechnol, 5(1):5-12.

[13] Henery, R.F. (1974): Clinical Chemistry Principles and Techniques. $2^{\text {nd }}$ Ed., Harper and Row, Hagerstein, M.D.

[14] Dumas, B.T.; Watson, W.A. and Biggs, H.G. (1971): Quantitative colorimetric determination of albumin in serum or plasma. Clin Chem Acta, 31:87-91

[15] Narayanan, P.R.; Acharula, G.S.; Krishman, U.P.; Abdul Rauoof, A. and Tripathy, S.P. (1993): Evaluation of ELISA as diagnostic test in pulmonary tuberculosis. Indian J Tuberc, 30(1):2932.

[16] Tamhane, A.C. and Dunlop, D.D. (2002): Statistics and data analysis: from elementary to intermediate (Vol. 1). Prentice Hall.

[17] Kohyama, T.; Takizawa, H.; Kawasaki S.; Akiyama, N.; Sato M and Ito, K. (1999): 
Fourteen-member macrolides inhibit interleukin-8 release by human eosinophils from atopic donors. Antimicrob Agents Chemother, 43(4): 907-911.

[18] Tamaoki, J.; Kadota, J. and Takizawa, H. (2004): Clinical implications of the immunomodulatory effects of macrolides. Am J Med, 117 (9): 5-11.

[19] Parnham, M.G.; Culic, O. and Erakovic, V. (2005): Modulation of neutrophil and Inflammation markers in COPD. Eur $\mathrm{J}$ Pharmacol, 517(1):132-143.

[20] Ishimatsu, Y.; Kadota, J.I.; Iwashita, T.; Nagata, T.; Ishii, H.; Shikuwa, C.; Kaida, H.; Mukae, H. and Kohno, S (2004): Macrolide antibiotics induce apoptosis of human peripheral lymphocytes in vitro. Int J Anrimicrob Agents, 24 (3): 247-253.

[21] Williams, A.C.; Galley, H.F.; Watt, A.M. and Webster, N.R. (2005): Differential effects of three antibiotics on $\mathrm{T}$ helper cell cytokine expression. J Antimicrob Chemother, 56 (3):502-506.

[22] Kikuchi, T.; Hagiwara, K.; Honda, Y.; Gomi, K.; Kobayashi, T.; Takahashi, H.; Tokue, Y.; Watanabe, A and Nukiwa, T. (2002): Clarithromycin suppresses lipopolysaccharide-induced interleukin-8 production by human monocytes through AP-1 and NF-kappa B transcription factors. $\mathrm{J}$ Antimicrob Chemother, 49(5):745-755.

[23] Yamasawa, H.; Oshikawa, K.; Ohno, S. and Sugiyama, Y. (2004): Macrolides inhibit epithelial cell-mediated neutrophil survival by modulating granulocyte macrophage colony-stimulating factor release. Am J Respir Cell Mol Biol, 30(4): 569-575.
[24] Luo, H.; Chen, H.; Daloze, P.; Chang, J.Y.; St-Louis, G. and Wu, J. (1992): Inhibition of in vitro immunoglobulin production by rapamycin. Transplant, 53 (5):1071-1076.

[25] J un, Y.T.; Kim, H.J.; Song, M.J.; Lim, J.H.; Lee, D.G.; Han, K.J.; Choi, S.M.; Yoo, J.H.; Shin, W.S and Choi, J.H. (2003): In vitro effects of ciprofloxacin and roxithromycin on apoptosis of jurkat $\mathrm{T}$ lymphocytes. Antimicrob Agents Chemother, 47 (3):1161-1164.

[26] Reuther, J.Y and Baldwin, A.S.Jr. (1999): Apoptosis promotes a caspase induced amino-terminal truncation of $\mathrm{I} \kappa \mathrm{B} \alpha$ that functions as a stable inhibitor of NF- $\mathrm{KB}$. J Biol Chem, 274(29): 20664-20670.

[27] Maletić, J.; Djelić, N.; Radaković, M.; Maletić, M.; Lakić, N.; Kukolj, V.; Aleksić, N.; Andjelković, M. and Stanimirović, Z. (2015): Evaluation of DNA damage in rat lymphocytes expose to tulathromycin in vitro. Genetika, 47 (1): 339-438.

[28] Scheel-Toellner, D.; Wang, K.Q.; Webb, P.R.; Wong, S.H.; Craddock, R.; Assi, L.K.; Salmon, M and Lord, J.M. (2004): Early events in spontaneous neutrophil apoptosis. Biochem Soc Trans, 32(3):461464.

[29] Naito, M.; Nagashima, K.; Mashima T. and Tsuruo, T. (1997): Phosphatidylserine externalization is a downstream event of interleukin- $1 \beta$-converting enzyme family protease activation during apoptosis. Blood, 89(6): 2060-2066. 


$$
\begin{aligned}
& \text { الملخص العربي } \\
& \text { التغيرات المناعية للتولاثرومايسين فى الارانب }
\end{aligned}
$$

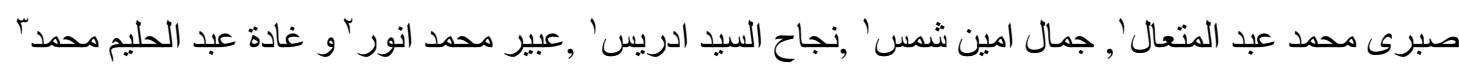

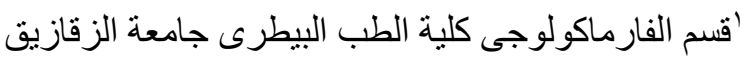

$$
\begin{aligned}
& \text { 'وحدة المناعة معهد تناسليات الهرم } \\
& \text { rمديرية الطب البيطرى محافظة الثرقية }
\end{aligned}
$$

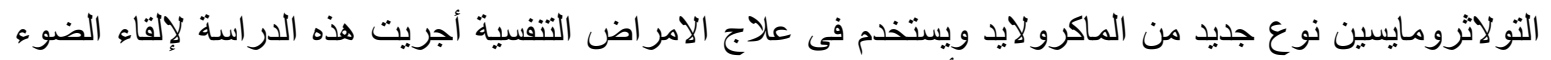

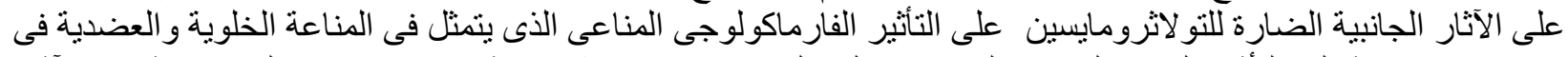

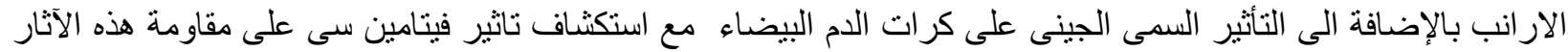

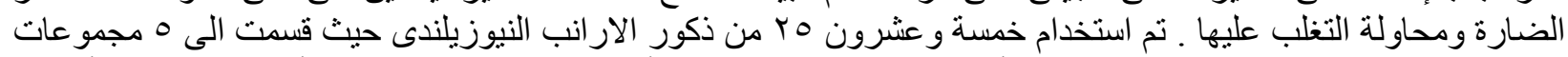

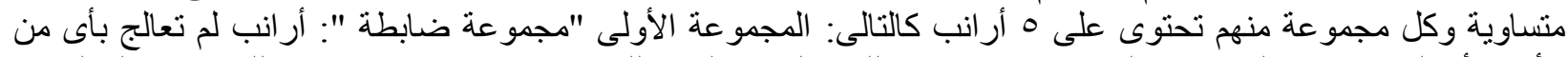

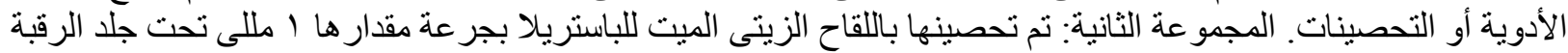

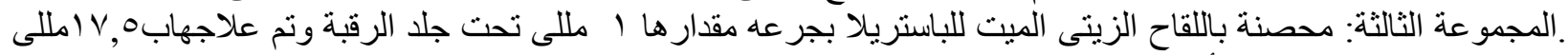

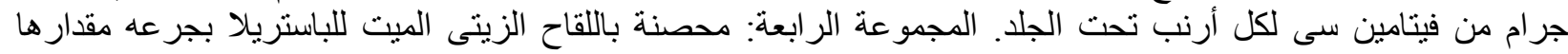

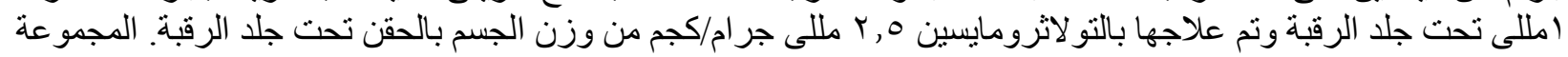

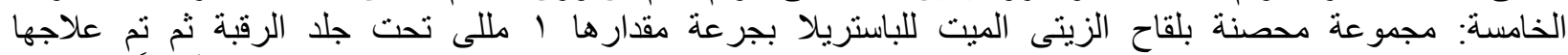

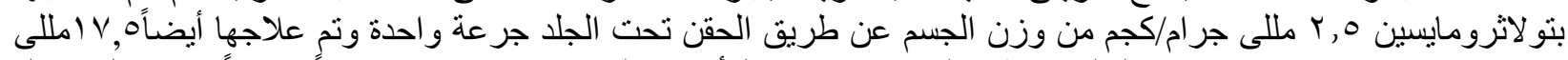

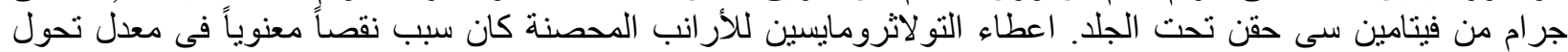

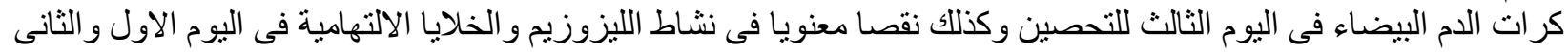

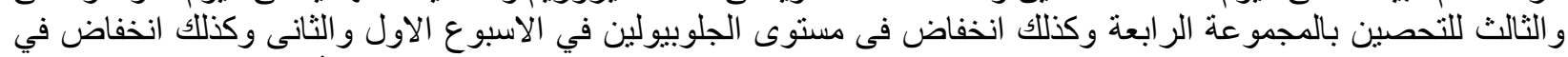

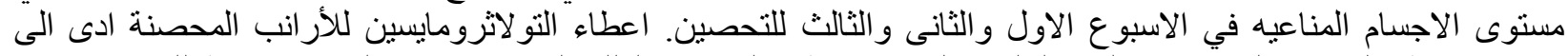

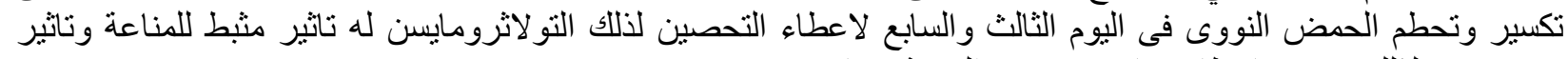

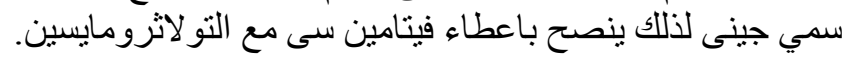

